\title{
UDC 621.9.04
}

\section{EXPERIMENTAL RESEARCH OF POWER PARAMETERS OF THE PROCESS OF FORMING A SHELF ON SCREW BLANK}

\author{
Ivan Hevko; Andrii Hypka; Olexandr Krugluk
}

\author{
Ternopil Ivan Puluj National Technical University, Ternopil, Ukraine
}

\begin{abstract}
Summary. The article presents the methodology and results of experimental investigations of shelf shaping processes on screw blank. Technological processes of curved profile shaping on the screw blanks with using screw mandrels and shaping roller are developed and experimentally tested. For their implementation, a set of technical equipment is designed and manufactured. As the experimental samples screw blanks were used with an outer diameter of 90, 104, $118 \mathrm{~mm}$, internal diameter of 50, 55, and $60 \mathrm{~mm}$, and screw thickness 1, 1.5, $2 \mathrm{~mm}$. Materials of screw blanks are steel $08 \mathrm{kp}$, steel 20, steel 30.
\end{abstract}

Key words: screw blank, shelf, experiment, shaping, equipment, SBCP.

Received 10.06.2017

Problem setting. Screw machine parts and tools are widely used in various fields of economy, and winding spiral with a curved profile (WSCP) is their variety. They are used as working bodies of screw conveyors, mixers, grinders, cleaners of agricultural machines and mechanisms. Therefore, both technological equipment to manufacture parts has been designed and produced and the technique of making a curved profile on the screw blanks (SB) by coiling for setting tight package has been developed.

Analysis of well-known research results. B.M. Hevko, R.M. Rohatynskyi [9], M.I. Pylypets [10] and V.V. Vasilkiv's [1] works are on the production of screw working bodies. L.M. Danylchenko [5], O.L. Lyashuk [11], A.P. Dragan [6], A.Ye. Diachun [7] and others $[2,4,8,12]$ investigated the problem of making special profile of screw working bodies. However, issues that arise during the manufacture of screw billets with curved profile have remained poorly investigated and require further elaboration.

The purpose of the research. The purpose of the work is to expand the structural and technological characteristics of screw spirals by effectively providing technological support to the process of execution on the cavernous workpiece of the curved profile.

Task setting. The current stage of development of the branches of the economy requires significant improvement of design and technological parameters and operational characteristics of machines and mechanisms, including ones with screw elements, which would allow to significantly increase the efficiency of production, improve the quality of products and reduce the cost of its production. The solution to these problems requires a thorough analysis of details of various types, including screw ones, and creation on their basis of more advanced, which requires the development of highly effective technologies for their production. In this regard, it is topical to study the characteristics of various types of screw manufacturing preparations, including specialized winding spirals with a curved profile (WSCP), which are widely used in transport and technological systems as workers of screw conveyors, mixers, grinders, granulators, separators, screw conveyors and spiral descents in the construction, food processing industry, powder metallurgy, agricultural machinery and others.

Presentation of the main material. When manufacturing WSCP it is necessary to consider, analyze and choose one of the main methods of its formation with given structural parameters. WSCP production is different from existing technology of typical straight cylindrical spirals that there is a need for an additional shelf at an angle, which requires the use 
or special equipment and tools, or additional manufacturing operations.

WSCP manufacturing is possible in the following ways:

a) rings stamping with a curved outer contour followed by welding into a spiral;

b) rolling of cylindrical straight spiral with subsequent shelf welding at the necessary angle;

c) winding a cylindrical straight spiral followed by shelf welding at the required angle;

d) bending of strips on the edge of a spiral simultaneously with the formation of a shelf at a certain angle;

e) bending of strips on the edge of a spiral with the subsequent operation of bending the shelf at a certain angle;

f) winding a spiral of profiled $\Gamma$-shaped billets on an edge with the advance forming of a shelf at a certain angle.

Other ways of making $\Gamma$-shaped spirals are either impossible or unproductive as they lead to significant cost overruns of energy, labor, time and complication characterized by significant process of WSCP manufacturing and the use of rolling and stamping methods are economically unjustified, because of energy costs. Thus, the formation of WSCP is technologically simpler and less energy-consuming and cost-effective in comparison with other methods. In addition, the process of guiding allows expanding of the technological capabilities of WSCP manufacturing through the use of universal devices. In general, the most rational methods of WSCP manufacturing are their winding on the internal profile end of rectangular billets with the simultaneous or subsequent formation of shelf [3]. In this process a high coefficient of material use is provided and significant welded joints are eliminated.

To confirm the proposed hypotheses of WSCP technological processes forming were developed and experimental studies were conducted to obtain various design parameters of the curved profile on the screw blanks (SB) in cross section using a molding tool for SB band of different sizes. In particular, a technological process of forming the curved profile on the spirals extended to the appropriate step with the use of screw frames and the shaping process were tested and experimentally tested. The features of forming the curved profile were determined by their geometric form. As experimental specimens, SBs with an external diameter of 90, 104, $118 \mathrm{~mm}$, with an internal diameter of $50,55,60 \mathrm{~mm}$ and a spiral turn thickness of 1, 1,5,2 mm were used. SB materials were steel 08, steel 20 and steel 30. The technological process, presented in the scheme in Fig. 1, foresaw shaping of a curved profile on spirals stretched to the appropriate step using screw frames, which have welded from one side of the rigidity ribs to hold the spiral of the screw from the bend in the direction of its forming.

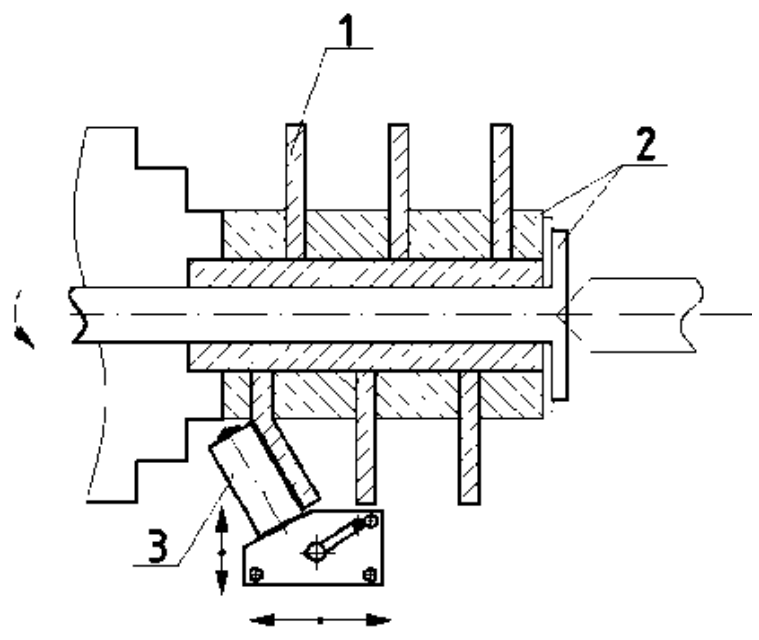

Figure 1. Scheme of WSCP forming process: 1 - screw; 2 - screw fixing; 3 - shaping tool 
Then the main drive and the machine were switched to the corresponding step of the spiral, which led to the formation of a curved profile on the investigated SB. To start the main motion of the machine and adjust the frequency of its rotation using the frequency converter Altivar and software PowerSuite v.2.5.0 were used. The bending force of the shelf was measured using the ALTIVAR 71 frequency converter, from which the personal computer came from. Results of changes in torque and engine power in time were obtained in the format of graphic and tabular dependencies in the window of the computer display program, as a percentage of the nominal values. To construct graphic dependencies, peak (maximal) values of the data obtained as a result of research were used.

Experiments using screw frames (Fig. 2) were performed with a threefold repetition. WSCP winding was carried out on lathe machines of models $16 \mathrm{~K} 20,16 \mathrm{E} 16 \mathrm{KP}$, where the spindle speed was pre-installed within $\omega=1.0 \ldots 1.5 \mathrm{~s}^{-1}$. The lathe chuck was fastened with a screw mount with the necessary geometric parameters. After, the investigated SB frame was placed, and the molding tool with its working surface was brought to the first turn of the spiral (Fig. 3).

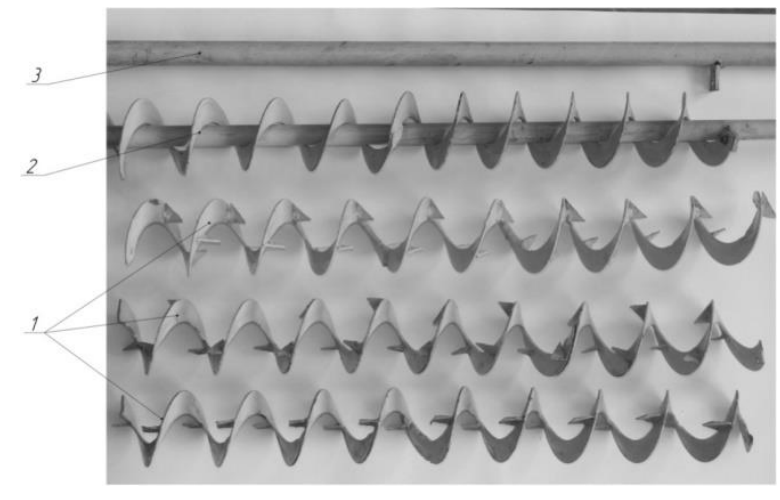

Figure 2. Screw mandrels:

1 - screws with increased rigidity; 2 - screw mandrels with fixed screws; 3 - shaft

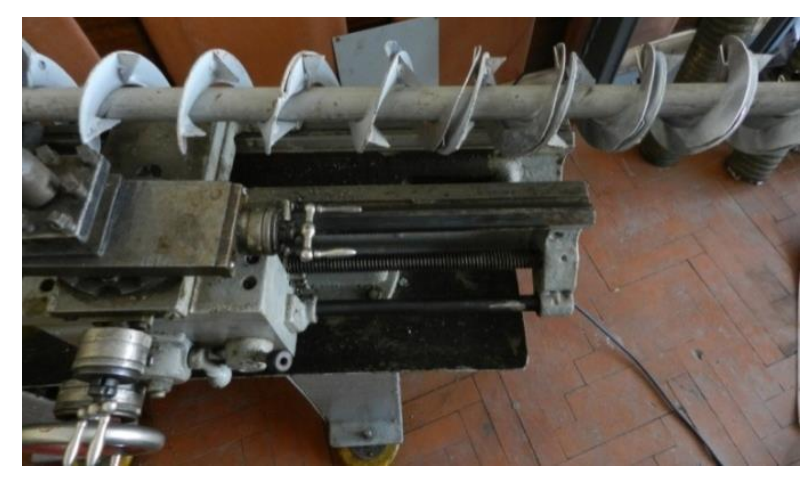

Figure 3. WSCP manufacturing with screw mandrel

We also developed and tested manufacturing process of forming a curved profile on SB dense package through forming bushings (Fig. 4), settings (Fig. 5) and roller forming (Fig. 6) with angles of the formative surface $\alpha$ to the axis of the spiral rotation $-15^{\circ}, 25^{\circ}, 35^{\circ}$ and the height of the vertical tape part $h-10,15,20 \mathrm{~mm}$. The frame with forming bushings and attached SB formed with a tight package was placed in the machine spindle and the roller with clamping washer and forming ring with the appropriate tilt work surface for SB shelf forming was fixed at a caliper machine. The working part of the device with a fixed roller interacts with the SB. The process of formation begins after the device set up and its interaction with SB with forming ring of the forming roller, the main motion and motion filing machine are turned on. After forming a curved profile on SB with reverse supply at the main motion machine calibration was performed on the piece of the roller forming at necessary step (Fig. 7 and Fig. 8). 

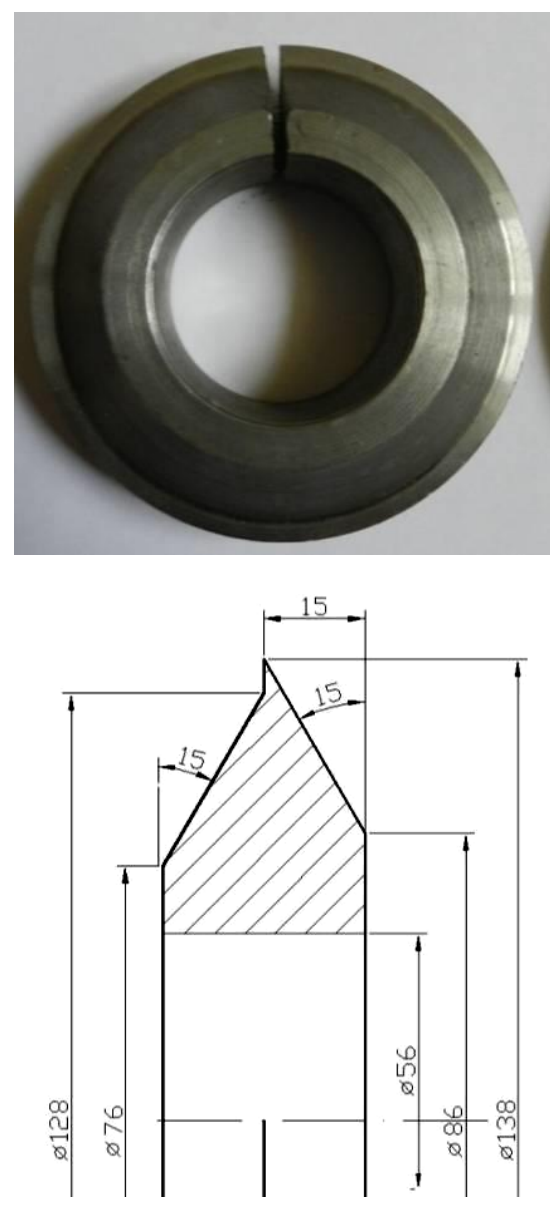

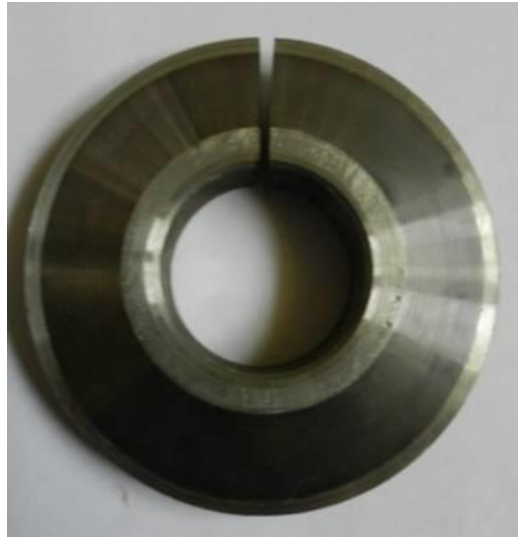

a)

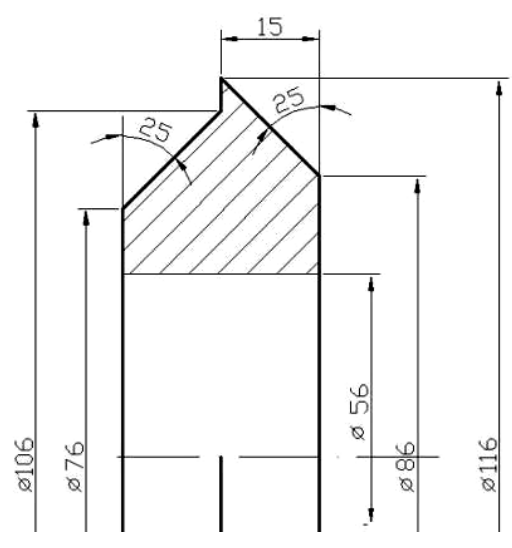

b)
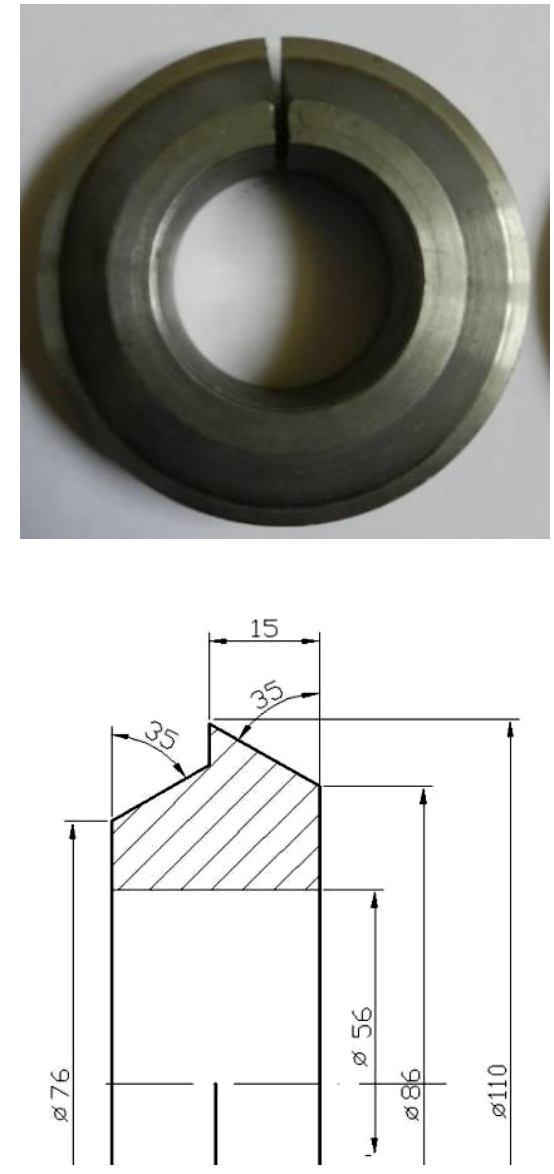

Figure 4. Shaping bushings: a) general view; b) design schemes

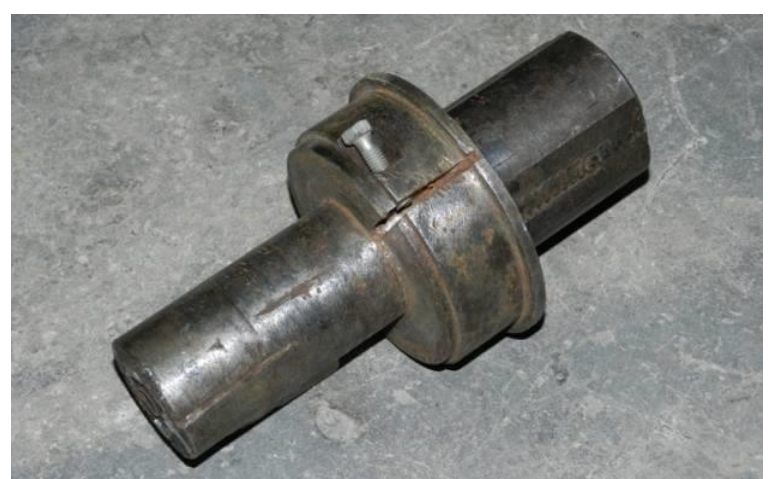

a)

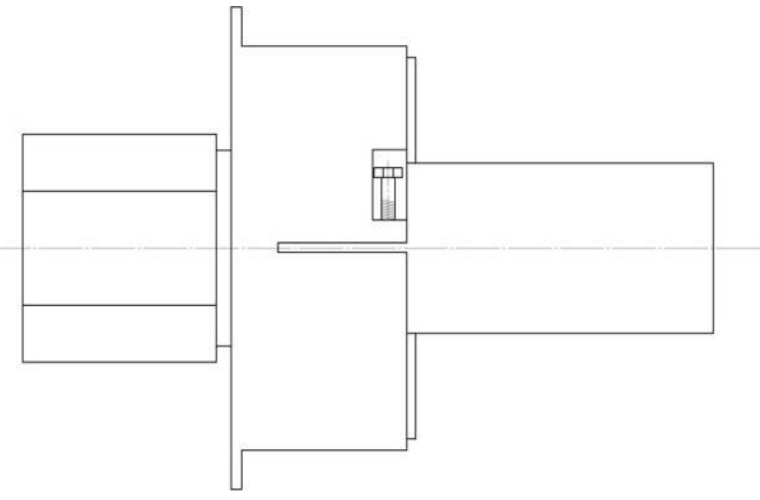

b)

Figure 5. Mandrel: a) general view; b) design scheme 


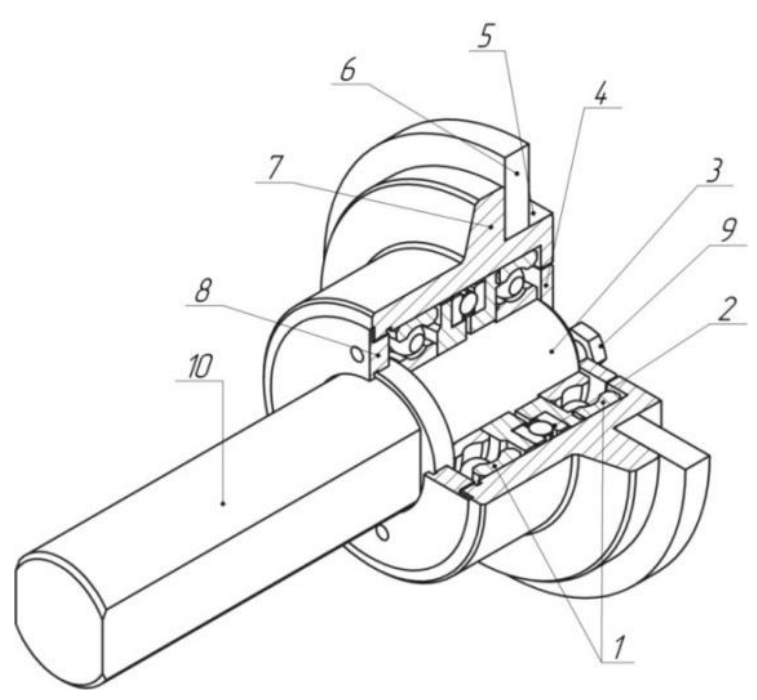

a)

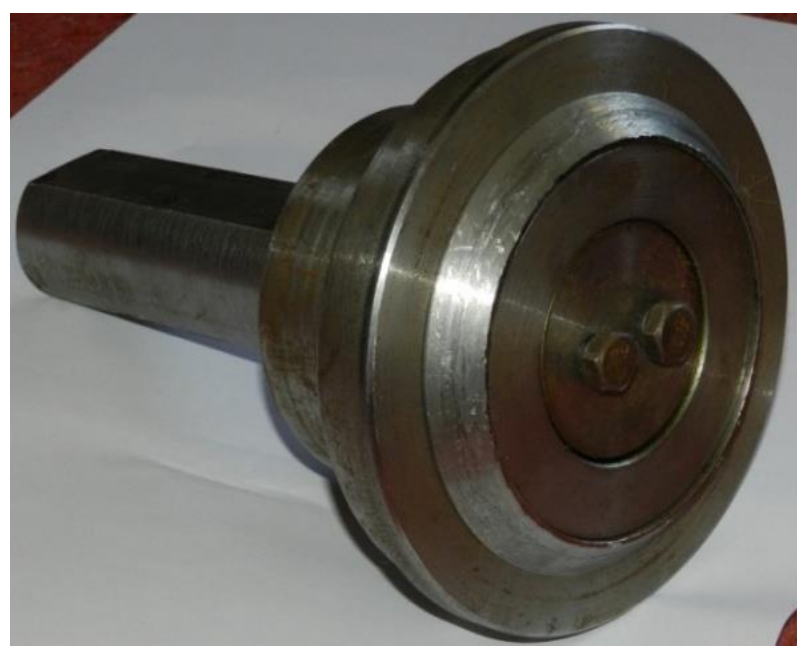

b)

Figure 6. Shaping roller: a) design scheme; b) general view

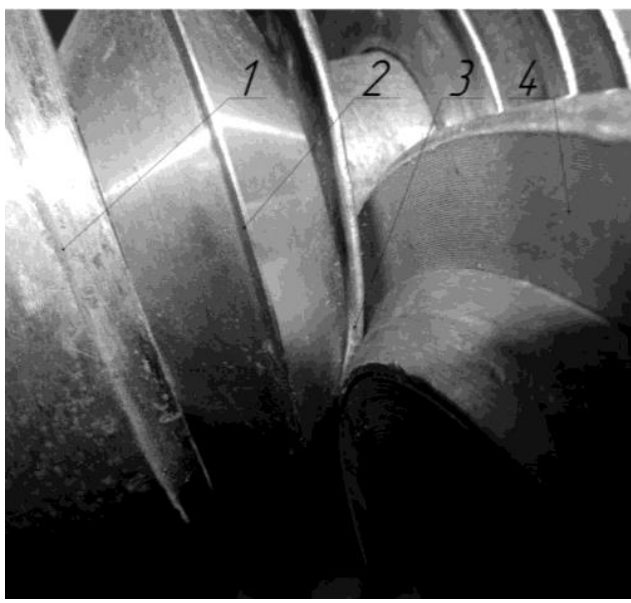

Figure 7. WSCP manufacturing with shaping tool: 1 - mandrel; 2 - bushing; 3 - curved profile; 4 - roller

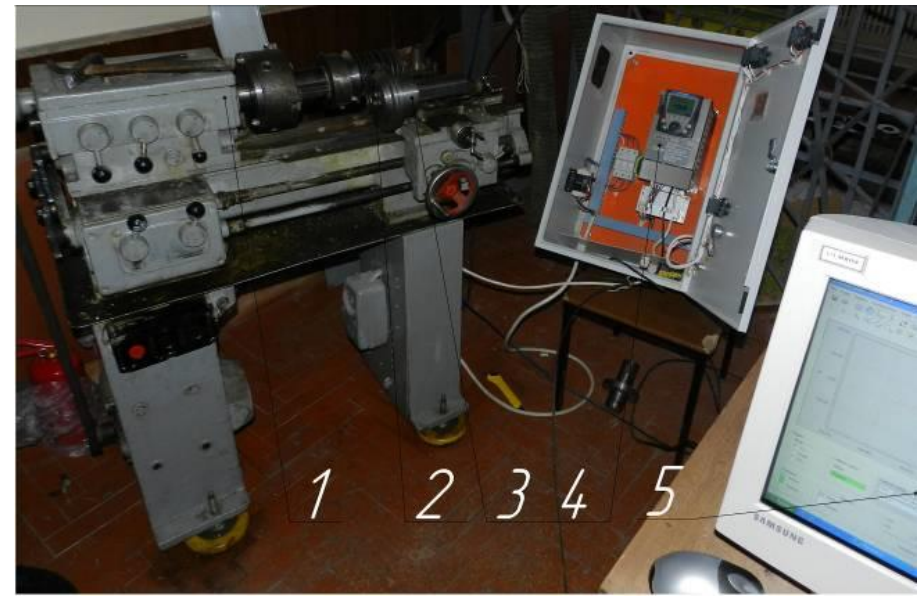

Figure 8. General view of stand equipment: 1 - machine; 2 - SB; 3 - shaping tool; 4 - Altivar; 5 - PC

The method of experimental research was supposed to carry out measurements of technological, power and structural parameters of the processes of bending the shelf on a spiral.

Experimental studies were carried out to determine the dependence of the bending forces on the thickness of the spiral, the diameter of the workpiece and the inclination angle of the molding sleeve, the realization of which was carried out by planning and conducting a threefactor experiment. In order to obtain a regression model of the optimization parameter in the form of a complete quadratic polynomial, the corresponding plan of the full-factor experiment was chosen, implementation of which was carried out in a well-known sequence. After processing the experimental data, the regression equations are given, which have the form:

- for the material of the workpiece (steel 08kp):

$$
\begin{aligned}
& M_{(\text {steel } 08 k p)}=93,31-2,26 D-93 s+1,79 \alpha+0,99 D s- \\
& -7 \cdot 10^{-3} D \alpha+0,55 s \alpha+0,012 D^{2}+3,76 s^{2}-0,029 \alpha^{2}
\end{aligned}
$$

- for the material of the workpiece (steel 20): 


$$
\begin{aligned}
& M_{(\text {steel 20) }}=105,2-2,53 D-102,82 s+1,95 \alpha+1,09 D s- \\
& -7,71 \cdot 10^{-3} D \alpha+0,61 s \alpha+0,014 D^{2}+4,28 s^{2}-0,031 \alpha^{2},
\end{aligned}
$$

- for the material of the workpiece (steel 30):

$$
\begin{aligned}
& M_{(\text {steel } 30)}=115,58-2,77 D-112,26 s+2,12 \alpha+1,19 D s- \\
& -8,43 \cdot 10^{-3} D \alpha+0,67 s \alpha+0,015 D^{2}+4,72 s^{2}-0,034 \alpha^{2} .
\end{aligned}
$$

The obtained regression dependences can be used to determine the torque of the shaping of a curved profile on a spiral within the parameters: $90 \mathrm{~mm} \leq 118 \mathrm{~mm} ; 150 £ 350 ; 1 \mathrm{~mm} £ \mathrm{~s}$ $£ 2 \mathrm{~mm}$. According to the obtained regression equations, the surface of the response is constructed, the graphic representations of which are shown in Fig. $9-11$.

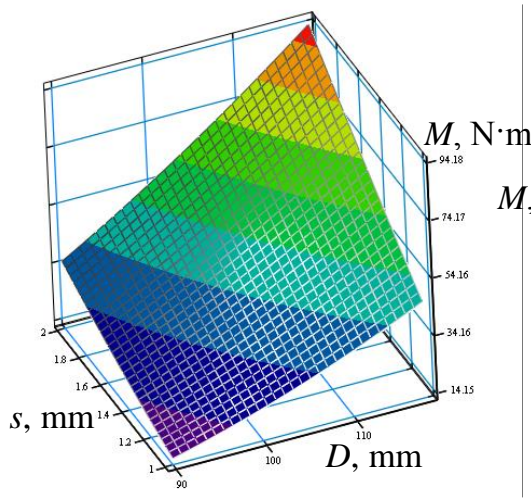

a)

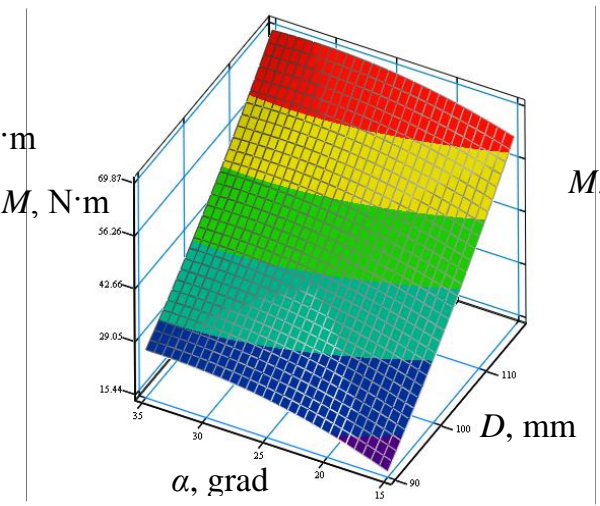

b)

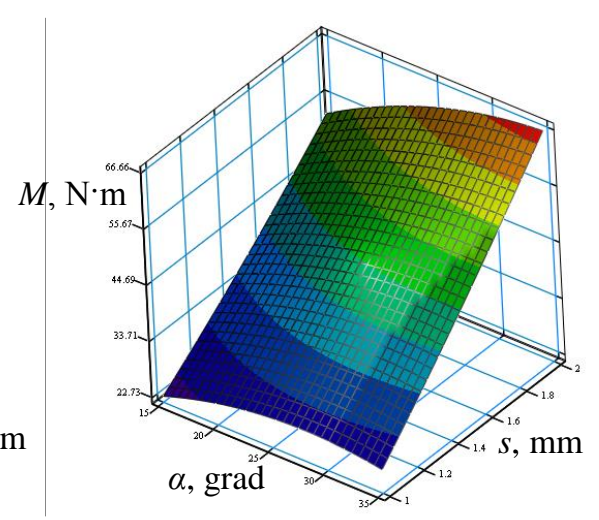

c)

Figure 9. The response surface of torque $M_{(D, s)}$ depends on shelf manufacture on screws made from steel $08 \mathrm{kp} \mathrm{a)} \alpha=25^{\circ}$; b) $s=1,5 \mathrm{~mm}$; c) $D=104 \mathrm{~mm}$

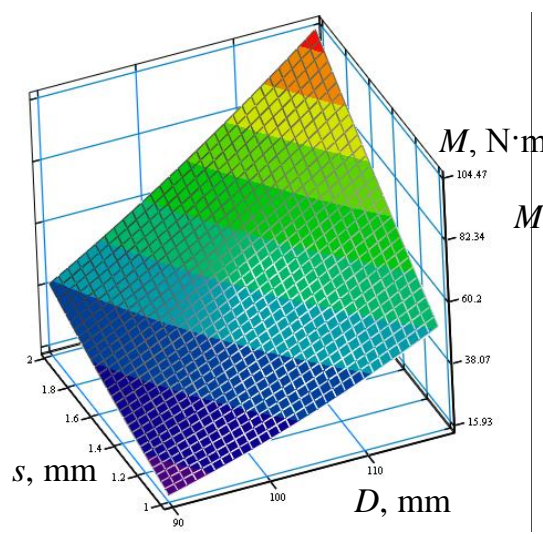

a)

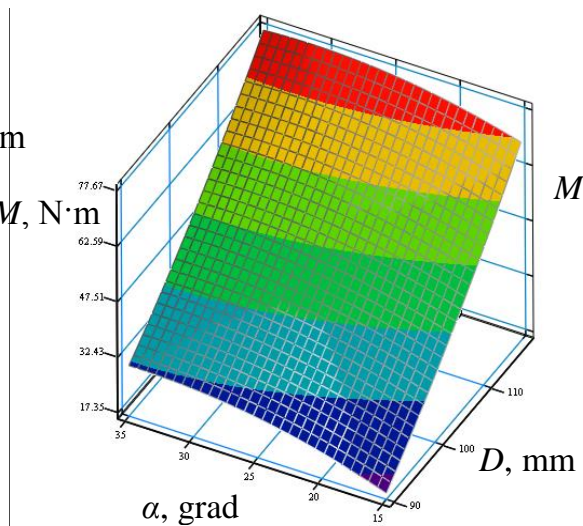

b)

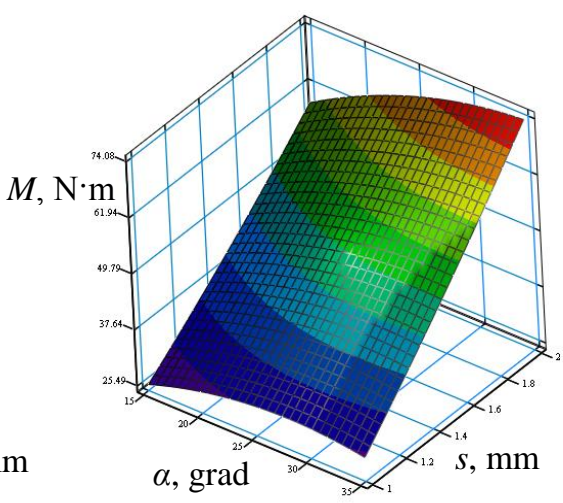

c)

Figure 10. The response surface of torque $M_{(D, s)}$ depends on shelf manufacture on screws made from steel 20: a) $\alpha=25^{\circ}$; b) $s=1,5 \mathrm{~mm}$; c) $D=104 \mathrm{~mm}$ 


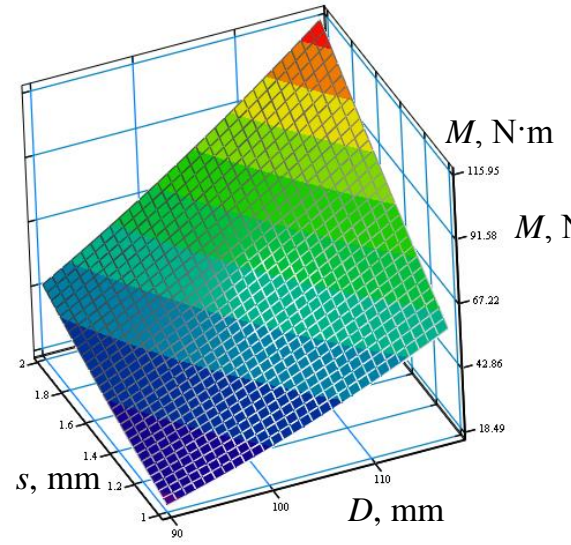

a)

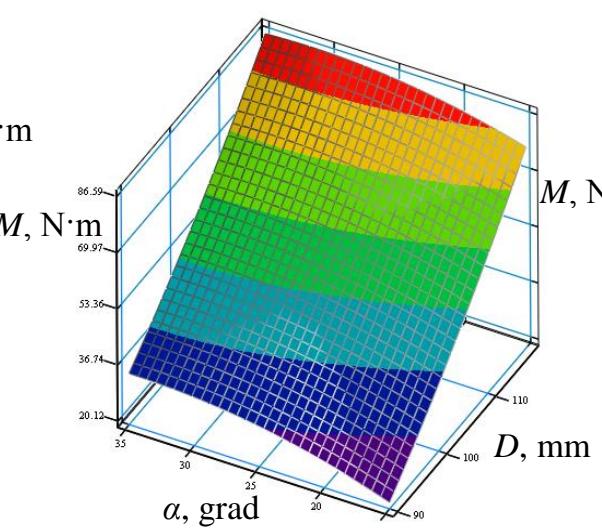

b)

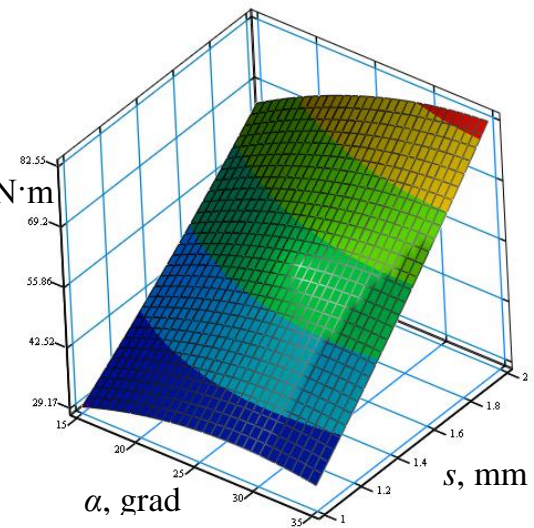

c)

Figure 11. The response surface of torque $M_{(D, s)}$ depends on shelf manufacture on screws made from steel 30: a) $\alpha=25^{\circ}$; b) $s=1,5 \mathrm{~mm}$; c) $D=104 \mathrm{~mm}$

As result of experimental studies, it has been established that the dominant factors affecting the torque value are the diameter of the propeller spiral D and the thickness of the spiral shelf $s$, and the angle of the shelf inclination $\alpha$ on the power parameters of the shaping process of the curved profile does not affect significantly. The torque changes are based on the diameter of the propeller spiral D and the thickness of the coil of the spiral $s$, which are in the range from 14 to $94 \mathrm{~N} \cdot \mathrm{m}$ for steel $08 \mathrm{kp}$, from 15 to $104 \mathrm{~N} \cdot \mathrm{m}$ for steel 20, and from 18 to 115 $\mathrm{N} \cdot \mathrm{m}$ for steel 30 at $\alpha=$ const. Also, by comparison of the two methods, one can conclude that the method of forming the curved profile on the SB molding roll in comparison with the method of this process when using a screw mandrel has several advantages:

- energy - effective;

- ensures uniform shaping of the curved profile on the SB providing the required accuracy of the angle inclination $\alpha$;

- avoids corrugation of the curved profile on the SB;

- can be used in the formation of a curved profile with a thickness $s$ of a coil of spiral more than $3 \mathrm{~mm}$;

- requires a much smaller amount of technological equipment, especially in the formation of a curved profile SB on various types and sizes.

It has been experimentally established that the method of conducting the shaping process of a curved profile on a screw mold on with a forming roll in comparison with the methodology of the process with the use of a screw mandrel has several advantages: energy effective; provides uniform shaping of the curved profile on the screw billet while providing the required accuracy of the angle of inclination $\alpha$; avoids corrugation of the curved profile on the screw billet; can be used for shaping a curved profile with a thickness $s$ of the spiral circle of more than $3 \mathrm{~mm}$; requires a much smaller amount of technological equipment, especially when shaping a curved profile on a screw billet of various sizes.

Conclusions. The technological processes of forming the curved profile on the SB using screw frames and forming roller have been developed and experimentally tested. In order to conduct them a set of technical equipment was designed and manufactured. As experimental specimens, SBs with an external diameter of 90,104, $118 \mathrm{~mm}$, with an internal diameter of 50, $55,60 \mathrm{~mm}$ and a spiral sheath of 1, 1,5, $2 \mathrm{~mm}$ were used. SB materials were: steel $08 \mathrm{kp}$, steel 20 and steel 30 .

It has been established that the dominant factors affecting the torque value are the diameter of the propeller spiral D and the shear spiral thickness $s$, and the angle of inclination of the shelf $\alpha$ on the power parameters of the forming process of the curved profile does not 
affect significantly. The torque changes are based on the diameter of the propeller spiral D and the thickness of the coil of the spiral s, which are in the range from 14 to $94 \mathrm{~N} \cdot \mathrm{m}$ for steel $08 \mathrm{kp}$, from 15 to $104 \mathrm{~N} \cdot \mathrm{m}$ for steel 20, and from 18 to $115 \mathrm{~N} \cdot \mathrm{m}$ for Steel 30 at $\alpha=$ const.

It has been experimentally established that the method of carrying out the process of forming the curved profile on a SB molding roll in comparison with the method of carrying out this process with the use of a screw mandrel has several advantages: it is energy - saving; provides uniform shaping of the curved profile on the screw billet while providing the required accuracy of the inclination angle $\alpha$; avoids corrugation of the curved profile on the screw billet; can be used for shaping a curved profile with a thickness s of spiral circle of more than $3 \mathrm{~mm}$; requires a much smaller amount of technological equipment, especially when shaping a curved profile on a screw billet of various sizes.

\section{References}

1. Vasyl'kiv V.V. Rozvytok naukovo-prykladnykh osnov rozroblennya tekhnolohiy vyrobnytstva hvyntovykh i shnekovykh zahotovok z vykorystannyam unifikatsiyi: dys. ... d-ra. tekhn. nauk: 05.02.08, Vasyl' Vasyl'ovych Vasyl'kiv; Nats. un-t „L'viv. Politekhnika“. L'viv, 2015, 312 p.

2. Hevko Iv. Syntez sposobiv navyvannya hvyntovykh zahotovok, Iv. Hevko, O. Katrych. Visnyk TNTU, Ternopil', 2015, vol. 80, no. 4, pp. $153-160$.

3. Hevko Iv.B., Harmatyuk O.O., Nahornyak H.S., Hupka A.B., Hevko O.-M.I. Tekhniko-ekonomichne obgruntuvannya vyboru sposobu vyhotovlennya vyhnutoho profilyu na hvyntovykh spiralyakh. Visnyk Kharkivs'koho natsional'noho tekhnichnoho universytetu sil's'koho hospodarstva imeni Petra Vasylenka. „Resursozberihayuchi tekhnolohiyi, materialy ta obladnannya u remontnomu vyrobnytstvi“, 2016. Vypusk no. 168 , pp. $97-103$.

4. Hupka A.B. Yssledovanye sylovыkh parametrov formoobrazovanyya profyl'nыkh vyntovыkh эlementov, Y.B. Hevko, Y.N. Kuchvara, A.Ye. Dyachun, A.B. Hupka. MOTROL. Commission of Motorization and Energetics in Agriculture, Lublin, 2015, vol. 17, no. 7, pp. 111 - 116.

5. Danyl'chenko L.M. Doslidzhennya napruzheno-deformovanoho stanu v protsesi formoutvorennya hnutykh zahotovok dlya hvyntovykh profiliv, L.M. Danyl'chenko, I.B. Hevko, A.P. Drahan. Mizhvuzivs'kyy zbirnyk (za napryamom „Inzhenerna mekhanika“): „Naukovi notatky“ LTDU, 2002, vyp. 10, pp. 49 - 57.

6. Drahan A.P. Teoretychni peredumovy tekhnolohichnoho protsesu vyhotovlennya hvyntovykh hofrovanykh zahotovok: dys... kand. tekhn. nauk: 05.02.08, Drahan Andriy Petrovych; Ternopil's'kyy derzh. tekhn. un-t im. I. Pulyuya, T., 2007, 198 p.

7. Dyachun A.Ye. Obgruntuvannya parametriv tekhnolohichnoho protsesu vyhotovlennya profil'nykh hvyntovykh zahotovok: dys. ... kand. tekhn. nauk: 05.02.08, Dyachun Andriy Yevhenovych; TDTU im. I. Pulyuya, T., 2008, 208 p.

8. Zhuravlev A.Z. Yz-hotovlenye shnekov dlya zernouborochnыkh kombaynov, A.Z. Zhuravlev, Yu.N. Verzylov, V.A. Ehorov, Kuznechno-shtampovochnoe proyzvodstvo. M., 1980, no. 5, pp. 29 - 31.

9. Mekhanizmy z hvyntovymy prystroyamy, B.M. Hevko, M.H. Danyl'chenko, R.M. Rohatyns'kyy ta in. L'viv : Svit, 1993, 208 p.

10. Pylypets' M.I. Naukovo-tekhnolohichni osnovy vyrobnytstva navyvnykh zahotovok detaley mashyn: dys... d-ra tekhn. nauk: 05.02.08, Mykhaylo Il'kovych Pylypets'; Nats. un-t „L'viv. Politekhnika“. L'viv, 2002, $445 \mathrm{p}$.

11. Tekhnolohichni osnovy formoutvorennya spetsial'nykh profil'nykh hvyntovykh detaley, B.M. Hevko, O.L. Lyashuk, I.B. Hevko ta in. Ternopil', TDTU imeni Ivana Pulyuya, 2008, 367 p.

12. Chris Rorres. The turn of the screw: optimal design of an Archimedes screw, Jornal of hydrauling, January 2000, pp. $72-80$.

\section{Список використаної літератури}

1. Васильків, В.В. Розвиток науково-прикладних основ розроблення технологій виробництва гвинтових і шнекових заготовок з використанням уніфікації: дис. ... д-ра. техн. наук: 05.02 .08 [Текст] / Василь Васильович Васильків; Нац. ун-т «Львів. політехніка». - Львів, 2015. - 312 с.

2. Гевко, Ів. Синтез способів навивання гвинтових заготовок [Текст] / Ів. Гевко, О. Катрич // Вісник ТНТУ. - Тернопіль, 2015. - Том 80, № 4. - С. 153 - 160.

3. Техніко-економічне обгрунтування вибору способу виготовлення вигнутого профілю на гвинтових спіралях [Текст] / Ів.Б. Гевко, О.О. Гарматюк, Г.С. Нагорняк, А.Б. Гупка, О.-М.І. Гевко // Вісник Харківського національного технічного університету сільського господарства імені Петра Василенка. «Ресурсозберігаючі технології, матеріали та обладнання у ремонтному виробництві»2016. - Випуск - № 168. - С. 97 - 103. 
4. Исследование силовых параметров формообразования профильных винтовых элементов [Текст] / И.Б. Гевко, И.Н. Кучвара, А.С. Дячун, А.Б. Гупка // MOTROL. Commission of Motorization and Energetics in Agriculture, Lublin, 2015, vol. 17, no. 7, pp. 111 - 116.

5. Данильченко, Л.М. Дослідження напружено-деформованого стану в процесі формоутворення гнутих заготовок для гвинтових профілів [Текст] / Л. М. Данильченко, І. Б. Гевко, А.П. Драган // Міжвузівський збірник (за напрямом «Інженерна механіка»): «Наукові нотатки» ЛТДУ. - 2002. Вип. 10. - С. $49-57$.

6. Драган, А.П. Теоретичні передумови технологічного процесу виготовлення гвинтових гофрованих заготовок: дис... канд. техн. наук: 05.02.08 [Текст] / Драган Андрій Петрович; Тернопільський держ. техн. ун-т ім. І. Пулюя. - Т., 2007. - 198 с.

7. Дячун, А.С. Обгрунтування параметрів технологічного процесу виготовлення профільних гвинтових заготовок: дис. ... канд. техн. наук: 05.02.08 [Текст] / Дячун Андрій Свгенович; ТДТУ ім. І. Пулюя. - Т. - 2008. - 208 с.

8. Журавлев, А.З. Изготовление шнеков для зерноуборочных комбайнов [Текст] / А.З. Журавлев, Ю.Н. Верзилов, В.А. Егоров // Кузнечно-штамповочное производство. - М., 1980. - №5. - С. 29 31.

9. Механізми з гвинтовими пристроями [Текст] / Б.М. Гевко, М.Г. Данильченко, Р.М. Рогатинський та ін. - Львів: Світ, 1993. - 208 с.

10. Пилипець, М.І. Науково-технологічні основи виробництва навивних заготовок деталей машин: дис... д-ра техн. наук: 05.02.08 [Текст] / Михайло Ількович Пилипець; Нац. ун-т «Львів. політехніка». - Львів, 2002. - 445 с.

11. Технологічні основи формоутворення спеціальних профільних гвинтових деталей [Текст] / Б.М. Гевко, О.Л. Ляшук, І.Б. Гевко та ін. - Тернопіль: ТДТУ імені Івана Пулюя, 2008. - 367 с.

12. Chris Rorres. The turn of the screw: optimal design of an Archimedes screw, Jornal of hydrauling, January 2000, pp. $72-80$.

\title{
УДК 621.9.04
}

\section{ЕКСПЕРИМЕНТАЛЬНІ ДОСЛІДЖЕННЯ СИЛОВИХ ПАРАМЕТРІВ ПРОЦЕСУ ФОРМОУТВОРЕННЯ ПОЛИЧКИ НА ГВИНТОВІЙ ЗАГОТОВЦІ}

\author{
Іван Гевко; Андрій Гупка; Олександр Круглик
Тернопільський національний технічний університет імені Івана Пулюя, Тернопіль, Україна

\begin{abstract}
Резюме. Представлено методику й результати експериментальних досліджень проиесів формоутворення полички на гвинтовій заготовці. Розроблено ц̆ експериментально апробовано технологічні прочеси формоутворення вигнутого профілю на гвинтових заготовках з використанням шнекових оправ $i$ формувальним роликом. Для їх реалізації спроектовано й виготовлено комплект технічного спорядження. В якості експериментальних зразків використовували гвинтові заготовки із зовнішнім діаметром 90, 104, 118 мм, з внутрішнім діаметром 50, 55, 60 мм та товщиною витка спіралі 1, 1,5, 2 мм. Матеріали гвинтових заготовок - сталь 08кп, сталь 20, сталь 30.

Ключові слова: гвинтова заготовка, поличка, експеримент, формоутворення, спорядження,
\end{abstract} $Г З В П$. 